Піріашвілі О. Б., к.е.н., с.н.с.

Держсавна установа «Інститут економіки та прогнозування Національної академії наук України» м. Київ, Україна

DOI: https://doi.org/10.30525/978-9934-26-125-1-7

\title{
ІНСТИТУЦІОНАЛІЗАЦІЯ ІНВЕСТИЦІЙНОГО ЗАБЕЗПЕЧЕННЯ КОНКУРЕНТОСПРОМОЖНОСТІ ЗАЛІЗНИЧНОГО ТРАНСПОРТУ ${ }^{1}$
}

Напрацювання провідного зарубіжного досвіду щодо підвищення конкурентоспроможності національних економік та підприємств в країнах з розвиненою ринковою економікою $\epsilon$ достатньо великим на сьогодні. Разом із цим цей провідний, унікальний досвід також свідчить про те, що через значні відмінності у рівні економічного розвитку країн методичні підходи, конкретні інструменти та економічні механізми

1 Публікацію підготовлено в рамках виконання НДР відомчої (прикладної) теми: «Розвиток конкуренції в секторах транспортної та енергетичної інфраструктури України» (Державний реєстраційний № 0119U001811) 
реалізації у практику підвищення конкурентоспроможності національних економік та підприємств повинні базуватись на конкурентних перевагах тієї країни, де саме функціонує даний сектор національної економіки.

Так, розглядаючи залізничну транспортну інфраструктуру необхідно підкреслити, що ця система, як $\mathrm{i}$ вся транспортна інфраструктура в цілому $\epsilon$ системоутворюючою галуззю, тому що забезпечує надійність в роботі промисловості, аграрного сектору та соціальної сфери, а також покращує логістику, підвищує конкурентоспроможність вітчизняних підприємств та збільшує товарообіг в країні загалом.

Відповідно до цього пропонуємо схематичне відображення впливу інституціонального середовища ринкового та неринкового типу на визначення принципів конкуренції в економічній діяльності на залізничному транспорті країни в сучасних соціально-економічних умовах, яку представлено на рисунку 1.

Так, сучасними принципами функціонування комплексу залізничного транспорту повинні бути [1, с. 82]:

- стратегічне бачення проблем галузі та країни, механізмів їх вирішення;

- максимально можлива орієнтація на власні можливості, здібності, компетенції i ресурсно-матеріальну базу виробництва, прозорість діяльності, відхід від тіньових схем вибору партнерів і контрагентів;

- повнота задоволення фінансових проблем;

- радикальність змін фінансового, технічного, організаційного та управлінського характеру до процесів євроінтеграції. 


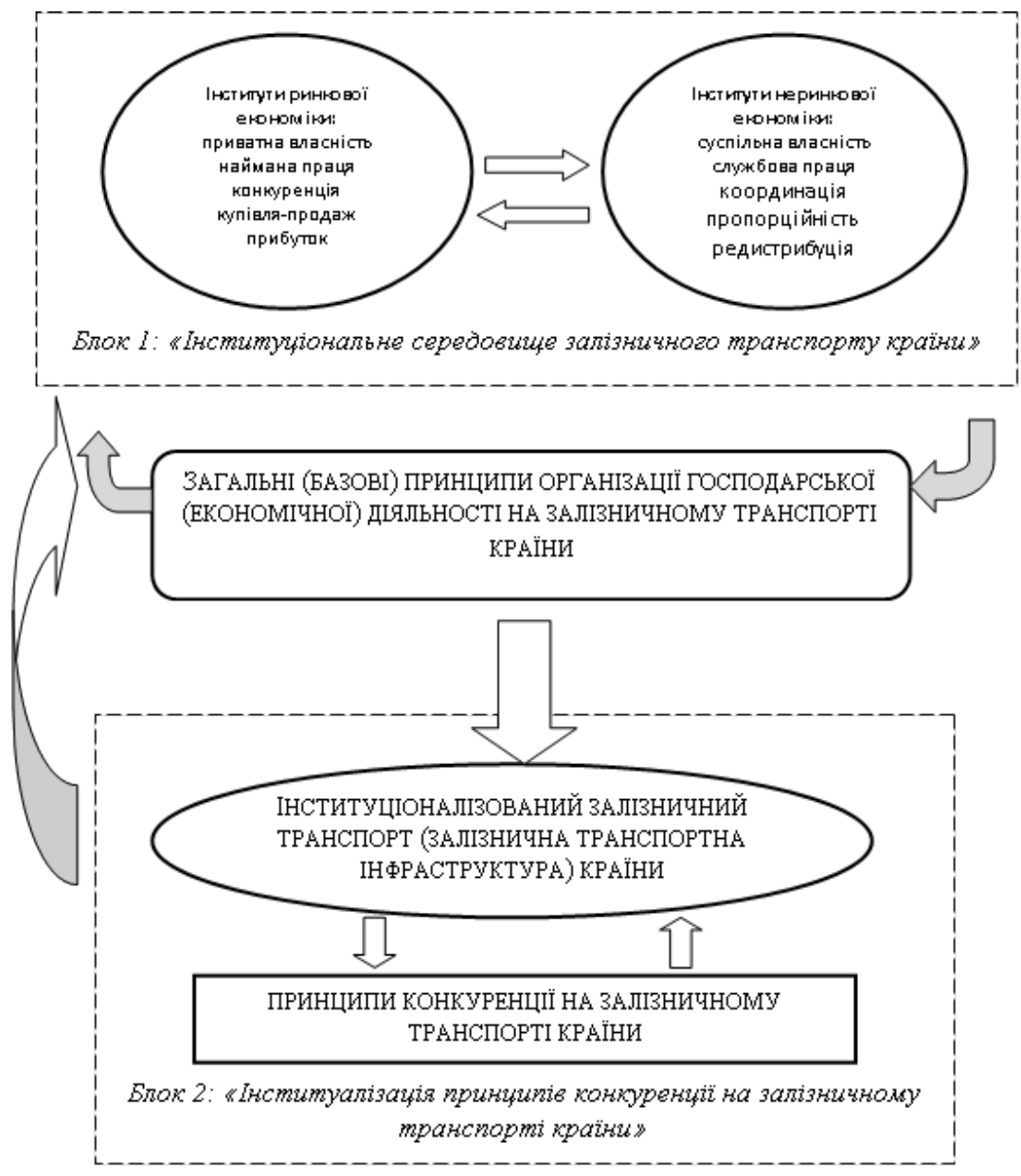

\section{Рис. 1. Схема генерації принципів конкуренції в інституціональному середовищі залізничного транспорту країни}

Джерело:авторська розробка

Проте, на нашу думку, АТ «Укрзалізниця» повинна залишатися в державній власності та бути природною монополією на ринку залізничних перевезень в Україні на сучасному етапі розвитку і в подальшій перспективі. Про 
що свідчить зарубіжний досвід державної системи управління (державна власність) залізницями в Німеччині, Швейцарії та Франції, тощо. Варто нагадати, що на сучасному етапі розвитку в світі існує три моделі розвитку та управління залізничним транспортом країни, а саме: 1) американська модель; 2) європейська модель; 3) азіатська модель. Яку з них впровадить Україна покаже практика, але все залежить від самої України. Необхідно забезпечити захист інвестицій 3 боку держави на внутрішньому ринку залізничних перевезень у розвиток залізничного транспорту України, зокрема, на оновлення та модернізацію рухомого складу, залізничних колій української залізниці у найближчій та віддаленій перспективі.

За оцінками експертів загальна потреба залізничної галузі в інвестиціях на оновлення основних фондів на найближчі 5 років оцінюється в сумі 175-200 млрд грн. Щорічна потреба Укрзалізниці в капітальних вкладеннях перевищує 35 млрд грн, у т.ч. на оновлення та модернізацію рухомого складу 24 млрд грн, на відновлення колійної інфраструктури - близько 6,8 млрд грн. При цьому останні 20 років потреба галузі в інвестиціях задовольняється лише на 25-30\% [2, с. 7].

До того ж, як зазначав Владислав Криклій, за підтримки СБРР, IFC та Глобального інфраструктурного фонду була розпочата робота над оцінкою варіантів залучення приватних інвестицій для розширення та підвищення ефективності регіональних залізничних вокзалів, а також для можливості створення відповідних спеціальних державних фондів для їх розвитку. Це не лише дозволить підвищити ефективність та сприятиме модернізації відповідної залізничної транспортної інфраструктури, але i 
забезпечить стабільне фінансування залізничної галузі, сформує чіткі механізми надання державної підтримки для проектів ДПП [4, с. 1-2].

У зв'язку з цим виникає питання про доцільність заміни іноземних громадян на вітчизняних фахівців та професіоналів високого класу, а також відповідно проведення повної ротації в складах Наглядової ради і в правлінні української залізничної компанії АТ «Укрзалізниця», які будуть відстоювати та захищати інтереси вітчизняної компанії та іï акціонерів.

Доцільно також, на нашу думку, розглянути ідею створення інноваційного залізничного кластеру на державному рівні чи регіональному рівні або галузевому рівнях господарювання в сучасних умовах економічної інтеграції.

Також необхідно терміново переглянути, переписати та підписати нові норми Угоди об Асоціації із Європейським Союзом в частинах щодо розвитку вітчизняного залізничного транспорту та вітчизняного транспортного машинобудування. (Стаття 29 Угоди говорить про те, що країни можуть оновлювати додатки до угоди без перегляду основного тексту угоди та без його повторної ратифікації) [3, с. 3]. Підсумовуючи, слід сказати, що у нашому конкретному випадку при розробці державної політики в сфері розвитку залізничної транспортної інфраструктури необхідно, на нашу думку, враховувати не тільки специфічні особливості даного об'єкту дослідження, але і специфіку розвитку самої країни на даному етапі розвитку, в якій зазначена організаційна структура функціонує та розвивається, а також той позитивний досвід практики управління залізничним транспортом, який Україна мала в минулому. 


\section{Література:}

1. Головкова Л.С., Омельчак Г.В. Забезпечення конкурентоспроможності залізничного транспорту України в умовах євроінтеграції. Збірник наукових праць Дніпропетровського національного університету залізничного транспорту імені академіка В. Лазаряна «Проблеми економіки транспорту», 2014. Вип. 7. С. 82.

2. Михайличенко К.М., Собкевич О.В. Удосконалення механізмів реформування та розвитку залізничного транспорту в контексті реалізації структурних реформ в галузі. Національний інститут стратегічних досліджень. Аналітична записка. URL: http://old2.niss.gov.ua/ articles/1662/

3. Ксенз Л. Исправленный договор с ЕС обрушит экспорт Украины. Итоги недели. 2021. 27 января - 2 февраля. № 4(806). С. 3.

4. Створення спецфондів для розвитку аеропортів і залізниці дозволить забезпечити стабільне фінансування цих галузей - Владислав Криклій. Міністерство інфраструктури України. 